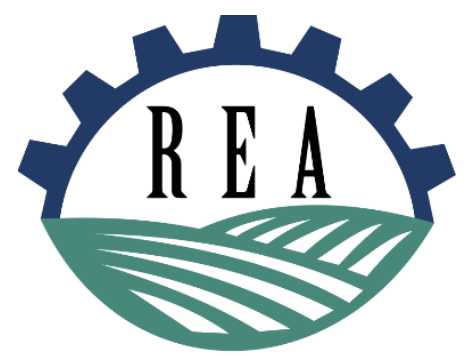

Revista de Economia e Agronegócio - REA

ISSN impresso: 1679-1614

ISSN online: $2526-5539$

Vol. 16 |N. 3 | 2018

EDITORIAL

\title{
CORN MARKET: BIG CHANGES, NEW PERSPECTIVES, AND FRESH RESEARCH OPPORTUNITIES
}

\author{
Fabio Mattos* \\ * University of Nebraska-Lincoln, Department of Agricultural Economics, \\ Lincoln, NE, USA. \\ E-mail: $\underline{\text { mattos@unl.edu }}$
}

In the late 1990's, the world population was 6 billion. The search engine Google had just been incorporated as a private company, the Bluetooth technology had just been announced, and Windows 98 had just been released by Microsoft. In financial markets, the Dow Jones Industrial Average had never traded above 10,000 points and crude oil prices were below $\$ 20 /$ barrel. Today, in 2018, about 20 years after the events listed above, the world population has already reached 7.7 billion. Google is one of the major private companies in the world, Bluetooth is widely used around the world, and few people remember that Windows 98 ever existed. The Dow Jones Industrial Average currently trades above 25,000 points, while crude oil prices have skyrocketed above $\$ 100 /$ barrel and currently trade around $\$ 60 /$ barrel. Even though the late 1990's is not too far away in our time line, it feels like a lifetime has passed since then.

Similarly, in the corn market, big changes have also happened in the last two decades. In the late 1990's, the United States was the dominant corn producer and exporter in the world, producing about 240 million metric tons ( $40 \%$ of world total) and exporting close to 50 million metric tons (65\% of world total). Brazil, on the other hand, was a minor player in the corn market, producing approximately 25 million metric tons ( $4 \%$ of world total) and exporting barely nothing. Ukraine had an even smaller participation in the world market. Corn was used mainly to feed livestock. USDA data shows that approximately $60-70 \%$ of total corn use was dedicated to feed, while most of the remaining quantity would go to food and industrial use. 
After many changes in the last two decades, we have a different corn market today. For the 2018/19 crop year, USDA projections show the United States producing 371 million metric tons (35\% of world total) and exporting 62 million metric tons (38\% of world total), Brazil producing 95 million metric tons ( $9 \%$ of world total) and exporting 29 million metric tons (18\% of world total), and Ukraine producing 34 million metric tons ( $3 \%$ of world total) and exporting 27 million metric tons (17\% of world total). The United States is still the largest exporter in the world, but its position is not as dominant as it used to be two decades ago. The participation of the United States in the world corn exports has almost halved within the last 20 years (from $65 \%$ to $38 \%$ ). During the same period, Brazil and Ukraine have emerged as two of the major exporters in the world and currently their combined participation in the world market is about the same as the U.S. share. In terms of corn use, it remains about the same in most countries, but there have been major changes in the U.S., where corn is now used almost in equal amounts to feed livestock and produce ethanol. The use of corn to feed livestock has dropped from about $60 \%$ to $35 \%$ of the U.S. total, while its use to produce ethanol has risen from barely nothing to approximately $35 \%$.

\section{New dynamics in the market and the role of Brazil}

These changes in a short period of time have created a new dynamics in the corn market. One of them is the change in the relationship between energy and agricultural markets with the large expansion of ethanol production from corn, which has been extensively explored in the literature (e.g. Hertel and Beckman, 2010; Tyner, 2010; TrujilloBarrera et al. 2012; Serra and Zilberman, 2013; Ahmadi et al., 2016). Although this price dynamics is still relatively recent and further studies will be needed in the future, much has been learned about the changing relationship between energy and agricultural prices. On the other hand, there is another topic that has been receiving little attention (partially because it is even more recent). As mentioned earlier, the U.S. lost its dominant position in the export market, and now the U.S. market share is about the same as Brazil's and Ukraine's shares combined. This changing structure of the corn export market can also have an impact on price dynamics.

The extraordinary expansion of Brazilian exports has been driven primarily by its ability to harvest two crops per year and by the strong growth of its winter crop, which has been reshaping the corn market within Brazil and in the international market. The winter crop started small and accounted for about $10 \%$ of total production in Brazil in the 1990 's. Nowadays, the winter crop accounts for approximately $70 \%$ of the Brazilian corn production, is predominantly grown in the centerwest and mostly shipped to the international market. These changes have led to changes in the seasonality of corn prices and basis in Brazil in the last few years, as well as a closer relationship between corn 
prices in Brazil and in the United States (Mattos and Silveira, 2015 and 2018). In addition, a study from the ERS-USDA discusses that, not only has Brazil rapidly increased its corn exports, but also its main export season now coincides with the period when the majority of the U.S. corn enters the international market (Allen and Valdes, 2016). This study discusses data suggesting changes in the export seasonality of U.S. corn due to this competition with Brazilian corn, with the primary exporting period shifting from October-January to February-April (which could bring downward pressure on U.S. corn prices at harvest).

These changes in the schedule of corn exports during the year can further affect price behavior. Arnade and Hoffman (2018) discuss the growing participation of Brazil and Ukraine as exporters in the corn world market based on data between 2003 and 2017. Although their sample period does not isolate the recent years in which Brazil and Ukraine gained larger market share, they still found that these two countries become relatively more influential in determining the world price after their respective harvests. The authors further indicate that the role played by Brazil and Ukraine in market pricing could potentially grow in the future. Recent projections prepared by the USDA suggest this is indeed a possibility. As they project that corn exports will increase by approximately $16 \%$ within the next 10 years, they indicate the U.S. will likely lose some market share in the world market while Brazil, Argentina and Ukraine are expected to continue expanding their exports (Ash et al., 2018). If market share continues shifting as discussed above, there will be larger volumes of corn exported from Brazil and Ukraine, establishing new trade flows around the world during the year. This can lead to further changes in price and basis seasonality across countries and in the world market, developing new price dynamics during the year and over time.

\section{Competitiveness in the world market}

As we look towards the future, another point to consider is competitiveness. Corn exported by Brazil comes mainly from the country's center-west, and then its competitiveness in the international market is grossly impacted by the transportation infrastructure in Brazil. A study from the ERS-USDA illustrates how the notoriously poor infrastructure in Brazil hurts its competitiveness in the world market (Meade et al., 2016). They calculated transportation costs of corn exported from the United States, Argentina and Brazil (large exporters in the world market) to Egypt and Japan (large importers in the world market). Table 1 shows these numbers for corn exported to Japan (numbers for corn exported to Egypt are very similar). For each country, they started with farm price (which essentially reflects production costs) and added transportation, handling, and other costs involved in hauling the grain from the farm to the export port. Specifically for Argentina, they also 
accounted for export taxes levied by the Argentine government and other export restrictions occasionally imposed (policy-related costs), which represent extra costs for farmers. Farm price plus the cost to move grain from the farm to the port gives us the FOB port price, which is the corn price at the port after it has been loaded onto the vessel. Finally, they added ocean transport cost to find the landed cost of corn in Japan, i.e. the price of corn from the United States, Argentina and Brazil when it arrives at the port in Japan.

Table 1. Estimated cost of transporting corn to Egypt, 2008-2012 average (US\$/metric ton)

\begin{tabular}{|c|c|c|c|}
\hline & $\begin{array}{l}\text { From U.S. } \\
\text { (Midwest) }\end{array}$ & $\begin{array}{l}\text { From } \\
\text { Argentina } \\
\text { (Heartland) }\end{array}$ & $\begin{array}{l}\text { From } \\
\text { Brazil } \\
\text { (Center- } \\
\text { west) }\end{array}$ \\
\hline Farm price & 204 & 138 & 182 \\
\hline $\begin{array}{l}\text { + Inland transport/ } \\
\text { handling cost }\end{array}$ & 39 & 43 & 102 \\
\hline $\begin{array}{l}\text { + Policy-related } \\
\text { costs }\end{array}$ & - & 104 & - \\
\hline $\begin{array}{l}=\text { FOB port price } \\
(*)\end{array}$ & 243 & 285 & 284 \\
\hline $\begin{array}{l}\text { + Ocean transport } \\
\text { cost }\end{array}$ & 34 & 37 & 37 \\
\hline$=$ Landed $\operatorname{cost}{ }^{(* *)}$ & 277 & 322 & 320 \\
\hline
\end{tabular}

$\left({ }^{*}\right)$ Corn price at the port in the country of origin after it has been loaded onto the vessel. $\left.{ }^{(*}\right)$ Corn price at the port in the destination country. Source: Meade et al., 2016.

As can be seen in Table 1, farm price is generally lower in Argentina and Brazil, reflecting lower production costs compared to the United States. Hence, they found that Argentina and Brazil are more competitive than the United States on the production side. When it comes to inland transport/handling costs, the numbers are roughly similar between United States and Argentina, but strikingly higher for Brazil. Brazilian costs are based on the center-west, where most of Brazilian corn is grown. The distance to the export ports in the east coast is about 1,000 miles, and the grain is hauled mostly by trucks through poorly-maintained highways. The mode of transportation and the poor infrastructure explains the high transportation cost for Brazil. They explain why, despite its competitiveness on the production side, Brazilian corn is generally not as competitive in the world market. On the other hand, competitiveness of Argentine corn is affected by the country's policy-related costs. Finally, ocean transport costs are basically the same across the table and have no significant impact on the relative competitiveness of the three countries.

The numbers in Table 1 essentially tell us that the United States manages to be more competitive in the world corn market because of 
their relatively low-cost and efficient transportation system (as opposed to the high-cost and inefficient transportation system in Brazil) and the absence of policy-related costs as in Argentina. However, this picture may not last forever. There have been efforts to improve the transportation system in Brazil. With more investments in infrastructure, improvement of highway conditions in the centerwest and development of inland waterways, Brazilian grain exports can become more competitive. With respect to Argentina, the government has been recently working to eliminate export taxes on corn. Hence, there should now be a very large reduction of the policyrelated costs in Table 1, helping make Argentine corn more competitive. As Brazil and Argentina work to reduce their costs and become more competitive as corn exporters, they may gain a larger market share in the world market.

This point complements the previous discussion about the changing market share. The competitiveness of Brazilian and Argentine corn (as discussed in Meade et al., 2016), along with Ukrainian corn, will help determine the participation of each country in the world market in coming years. Not only should we pay attention to the projected shift in market share, but also in how it happens. Potential modifications in relative prices across those countries can also lead to more changes in price dynamics within countries and in the world market.

\section{Are these changes going to affect futures markets and price discovery?}

Commodities largely traded across the globe are typically priced based on a benchmark. In the corn market, the benchmark has traditionally been the futures price traded in the Chicago Board of Trade (which is now part of the CME Group). In the world of agricultural commodities, there is typically one futures contract for each commodity. It is unusual to find more than one futures contract on the same commodity (except for commodities with different varieties, such as wheat and coffee), mostly because of the inertia of liquidity. The success of futures markets in commodities, equities, currencies and other asset classes relies, among other things, on the fact that it concentrates in the same place a large number of buyers and sellers willing to do business. This is actually one of the main reasons why futures markets were created a long time ago, i.e. to offer buyers and sellers a centralized marketplace where it would be easier and faster to find someone to trade with at a price that was satisfactory for both sides of the trade.

An old adage in futures markets says, "Liquidity begets liquidity". Markets with high trading activity will often attract more traders, while markets with low trading activity will rarely attract more traders. For any new futures contract, the main challenge is how to attract enough traders to create sufficient activity that will encourage other traders to join the market. If a new futures contract is created, 
traders (both hedgers and speculators) will essentially be asking the questions: "Can the new contract give me something that the existing contract cannot?" and "Will I benefit from the new contract even if it may not be as highly traded as the existing contract?" (Working, 1953; Silber, 1981; and Pennings and Leuthold, 2001 offer some interesting insights about this topic). The dominance of the corn futures market at the Chicago Board of Trade has been largely determined by its long history and the position of the United States as the major corn producer and exporter in the world. However, it is worth watching how those recent changes in the corn market may affect futures markets.

New developments in different commodity markets over time have created more interest in new futures contracts. For example, a recent article about the wheat market discusses how the decline of U.S. share in production and exports and the emergence of former Soviet Union countries (specifically Russia, Ukraine and Kazakhstan) as large exporters may be changing wheat price dynamics in the world (Janzen and Adjemian, 2017). The growing importance of wheat production in Europe would make local supply and demand relatively more relevant to determine wheat prices in Europe. Hence, European producers and merchandisers would naturally seek a futures contract based in Europe, which should better reflect their supply and demand conditions and should allow them to manage their local basis more effectively. The article argues that this is one of the main reasons behind the increase in trading activity for the futures contract on milling wheat offered by the Euronext exchange in Paris in recent years. The U.S. futures markets for wheat are still the central stage for wheat pricing in the world market, but the European futures market for milling wheat has also become an important pricing platform.

Back to the corn market, if the scenario of growing participation of Brazil and Ukraine and relatively smaller share of the United States in the world market continues to unfold, it will raise the question of whether U.S. markets will remain as the central stage for corn pricing in the world. This raises a further question of whether there will still be enough price correlation between the United States and other countries for producers and merchandisers around the world to use the Chicago futures contract to hedge their corn transactions. If corn prices in Brazil, Ukraine, China or other countries become less correlated with the corn price in the United States, the local basis in those countries will be less predictable and hence the hedging with Chicago futures contracts will become relatively less effective. In this scenario, new futures contracts for corn based in South America and/or Europe (or an increasing trading activity in the contracts already offered by B3 in Brazil and Euronext in France) may become viable. 


\section{Final remarks}

Overall, there are many research questions to be explored in the corn market, mostly involving the recent changes in trade flows and price dynamics across countries and their implications on risk management approaches, hedging, marketing and merchandising strategies, and government policy. Existing literature is somewhat limited as it generally provides only a broad description of the current situation, lacking a more comprehensive analysis of the research problems, both in terms of institutional knowledge and quantitative procedures. In addition, markets are dynamic by nature, hence new questions and opportunities for research may emerge in coming years.

As we wonder about future developments, it might be worth paying attention to a few points. One is the current disputes involving trade restrictions, notably between the United States and China. A large portion of recent changes in the corn market is related to changes in trade flows around the world. If they are disrupted, a new trade environment will unfold, which could further alter price relationships discussed earlier. Another point is the use of corn for ethanol production. The United States is the main producer of ethanol from corn in the world, but other countries have started following the same path, such as Brazil. Although it currently represents a negligible percentage, Brazil's use of corn as an alternative to sugarcane for biofuel production has grown recently. It is still unclear where it will head in coming years, but its development may add another piece that can change the corn market in the future. Another point is the participation of China in the world market, particularly the role of their futures markets as a pricing platform for commodities. There have been futures contracts for agricultural commodities in China for many years, such as the ones traded at the Dalian Commodity Exchange. The growing participation of China in the world market for commodities (such as corn and soybeans) resembles the case of wheat discussed earlier, although in much larger magnitude. However, there are restrictions for foreign traders who want to trade in futures markets in China, which limits the ability of these futures markets to become active pricing platforms for commodities in the world market. If these restrictions are ever lifted, price discovery in the world market could become more disperse than it is today and China may gain a larger role.

In conclusion, the corn market lives in a different world than it did 20 years ago. More research is needed to fully understand how these changes are reshaping the market and what the implications are for grain producers, merchandisers, traders and other market participants. Further, there may be even more changes in the future and we need to follow closely the next developments around the world. Brazil, for instance, could become the major force in the corn market. A few years ago, a study from the Brazilian Agricultural Research Corporation (Conab) estimated that under proper weather conditions and with appropriate financial and technological support, 
Brazilian producers would be able to more than double their winter corn production in the next decade (Landau et al., 2015). If this really happens and is accompanied by improvements in infrastructure, there could be large implications to the world market. Once I heard that "When Brazil decides to do something, it does it well, it does it big, and it does it quickly". Things in Brazil are definitely not as easy as they may sound in this statement, but there is still some true to it. Perhaps in 20 years from today, someone will write an article discussing more changes in the corn market. In the meantime, researchers interested in this topic should already have a full plate of research questions to work on.

\section{References}

AHMADI, M.; BEHMIRI, N.B.; MANERA, M. How is Volatility in Commodity Markets Linked to Oil Price Shocks? Energy Economics, v. 59, 2016.

ALLEN, E.; VALDES, C. Brazil's Corn Industry and the Effect on the Seasonal Pattern of U.S. Corn Exports. AES-93, U.S. Department of Agriculture, Economic Research Service, June 2016.

ARNADE, C.; HOFFMAN, L. Are Corn Prices Influenced by Brazil's and Ukraine's Growing Exports? Proceedings of the Agricultural and Applied Economics Association Annual Meeting, 2018.

ASH, M. et al. An Exploration of Crop Markets: A Deeper Look Into the USDA Crop Baseline Projections. FDS-18J-01, U.S. Department of Agriculture, Economic Research Service, October 2018.

HERTEL, T.W.; BECKMAN, J. Commodity Price Volatility in the Biofuel Era: An Examination of the Linkage between Energy and Agricultural Markets. National Bureau of Economic Research. University of Chicago Press, 2012.

JANZEN, J.P.; ADJEMIAN, M.K. Estimating the Location of World Wheat Price Discovery. American Journal of Agricultural Economics v. 99, n. 5, 2017.

LANDAU, E.C. et al. Expansão Potencial Da Produção De Milho $2^{\mathrm{a}}$ Safra No Brasil No Sistema De Sucessão Soja-Milho Considerando O Zoneamento De Risco Climático 2014/15. Boletim de Pesquisa e Desenvolvimento, v. 124, Embrapa (Brazilian Agricultural Research Corporation), December 2015.

MATTOS, F.; SILVEIRA, R. The Effects of Brazilian Second (Winter) Corn Crop on Price Seasonality, Basis Behavior and Integration to International Market. Proceedings of the NCCC-134 Conference on Applied Commodity Price Analysis, Forecasting and Market Risk Management, 2015. 
MATTOS, F.; SILVEIRA, R. The expansion of Brazilian winter corn crop and its impact on price transmission. International Journal of Financial Studies, v. 6, n. 45, 2018.

MEADE, B. et al. Corn and Soybean Production Costs and Export Competitiveness in Argentina, Brazil, and the United States. EIB-154, U.S. Department of Agriculture, Economic Research Service, June 2016.

PENNINGS, J.M.E.; LEUTHOLD, R.M. Introducing New Futures Contracts: Reinforcement versus Cannibalism. Journal of International Money and Finance, v. 20, 2001.

SERRA, T.; ZILBERMAN, D. Biofuel-related Price Transmission Literature: A Review. Energy Economics, v. 37, 2013.

SILBER, W.L. Innovation, Competition, ad New Contract Design in Futures Market. Journal of Futures Markets, v. 1, 1981.

TRUJILLO-BARRERA, A.; MALLORY, M.; GARCIA, P. Volatility Spillovers in the U.S. Crude Oil, Ethanol, and Corn Futures Markets. Journal of Agricultural and Resource Economics, v. 37, 2012.

TYNER, W.E. The Integration of Energy and Agricultural Markets. Agricultural Economics, v. 41, 2010.

WORKING, H. Futures Trading and Hedging. American Economic Review, v. 43, 1953. 